\title{
Use of an image intensifier for the localization and removal of a foreign body in the lower lip
}

\author{
Uso de intensificador de imagem para localização e remoção de corpo \\ estranho em lábio superior \\ Uso de un intensificador de imagen para localización y eliminación de \\ cuerpo extraño en el labio inferior \\ Gabriel MULINARI-SANTOS ${ }^{1}$ \\ João Paulo BONARDI ${ }^{1}$ \\ André Luís da Silva FABRIS ${ }^{2}$ \\ Igor de Oliveira PUTTINI ${ }^{1}$ \\ Juliana Zorzi COLÉTE ${ }^{1}$ \\ Ciro Borges DUAILIBE-de-DEUS ${ }^{1}$ \\ Leonardo Perez FAVERANI ${ }^{2}$ \\ Idelmo Rangel GARCIA-JÚNIOR ${ }^{2}$ \\ Francisley Ávila SOUZA² \\ ${ }^{I}$ Doutorando em Cirurgia e Traumatologia Bucomaxilofacial, Faculdade de Odontologia de Araçatuba, \\ UNESP-Univ. Estadual Paulista, 16015-050 Araçatuba-SP, Brasil \\ ${ }^{2}$ Departamento de Cirurgia e Clínica Integrada, Faculdade de Odontologia de Araçatuba, \\ UNESP-Univ. Estadual Paulista, 16015-050 Araçatuba-SP, Brasil
}

\begin{abstract} the patient.

Descriptors: Foreign Bodies; Fluoroscopy; Traumatology.
\end{abstract}

Foreign bodies can be found in the soft tissues of the face and in the maxillary bones in routine radiographic examinations. In the majority they do not present symptomatology. The removal of foreign bodies without the accurate location can cause severe complications. We present a case of 44-year-old male complaining an unusual foreign body in the lower lip region. Radiography did not reveal the exact location, and did not let a resolution at first time. Subsequently, the surgical treatment was effective with the aid of navigation-assisted fluoroscopy that showed the precise location of the foreign body for removal and avoided more discomfort to

\section{Resumo}

Corpos estranhos podem ser encontrados nos tecidos moles da face e nos ossos maxilares em exames radiográficos de rotina. Na sua maioria não apresentam sintomatologia. A remoção de corpos estranhos sem a localização precisa pode causar complicações severas. Apresentaremos um caso de um paciente com 44 anos com um corpo estranho incomum em lábio superior. Radiograficamente não foi possível ver a exata posição, e não foi possível resolver o caso. Na sequência, o tratamento cirúrgico foi efetivo com uso de da navegação assistida de fluoroscopia que mostrou a localização precisa do corpo estranho, para remoção e para evitar maiores desconfortos ao paciente.

Descritores: Corpos Estranhos; Fluoroscopia; Traumatologia.

\section{Resumen}

Los cuerpos extraños se pueden encontrar en los tejidos blandos de la cara y en los huesos maxilares en los exámenes radiográficos de rutina. En su mayoría no presentan sintomatología. La eliminación de cuerpos extraños sin la ubicación precisa puede causar complicaciones severas. Presentaremos un caso de un paciente con 44 años con un cuerpo extraño inusual en labio superior. Radiográficamente no fue posible ver la posición exacta, y no fue posible resolver el caso. En consecuencia, el tratamiento quirúrgico fue efectivo con el uso de la navegación asistida de fluoroscopia que mostró la localización precisa del cuerpo extraño, para remoción y para evitar mayores molestias al paciente.

Descriptores: Cuerpos Extraños; Fluoroscopía; Traumatología.

\section{INTRODUCTION}

The presence of foreign body (FB) is constantly a surgical challenge, especially on maxillofacial region ${ }^{1}$. FBs are a hazard when inside the submucosal tissue; due to anatomical proximity to critical nerves and vessels structures that can be injured, thus often they require removal ${ }^{2}$. In addition, the surgery without the precise location can cause severe complications such as infection, bleeding and hematoma ${ }^{3}$. Therefore, the removal of them is supposed to be a risk factor in maxillofacial surgery.

It is essential detect the exact location of FB for removal $^{2,4}$. However, identifying the position of these objects and determining a safe surgical approach are difficult using conventional preoperative radiography ${ }^{5}$. For this reason, several methods have been used, such as: plain radiographs, computed tomograms, magnetic resonance, and ultrasound, nonetheless an accurate determination of its location in the complex craniofacial region can be difficult, mainly if the FB is not next to an anatomic landmark ${ }^{5}$.

Fluoroscopy, using an x-ray machine with an image intensifier, has applications in many parts of medicine ${ }^{6}$. It was first used in neurosurgery to improve the imaging of brain tumors, cysts, edema and diagnosis of central nervous system diseases. ${ }^{7}$. The benefit exceeds surgery on the brain; fluoroscopy has been used a non -invasive method for guided surgical, due to the accuracy of location for removal of $\mathrm{FB}^{4}$. Also others reports demonstrate that fluoroscopy improves the management and resolution to removal of broken instruments and neddles in soft and hard tissue $e^{3,8,9}$.

In this case, the authors share their experience of an ineffectual tentative attempt of removal an unusual FB with conventional preoperative radiography and the effective resolution with the aid of a fluoroscopy for the localization and removal of a foreign body in the lower lip.

\section{CLINICAL CASE}

A 44-year-old male patient was referred to the Maxillofacial Surgery Service from FOA-UNESP, for treatment of a FB (fish-hook fragment) in the lower lip region. The patient hit him in the face and embedded in his lower lip a fish-hook, had cut off part of the foreign body previously by himself, and the rest remained inside lower lip subcutaneous region. Patient denied habits, allergies and comorbidity. Extraorally, he showed edema and a little entry hole of the FB in the lower lip. The FB was not clinically palpable. At first, it was performed an attempt of removal with local anesthesia, and aid of a conventional preoperative radiography. Additional with the problematic that the FB was not palpable, also it was difficult to determinate the correct position of FB in the plans radiography, (Figures 1and 2), consequently was not detected the FB in the first approach. After 1 week, a surgical navigation with a mobile fluoroscopy "C-arm" (Siemens AG, Multimobil 5c model, German) under 
local anesthesia was performed. In this time, the exact position of the foreign body was demarcated in the real-time image, by using a pen tip positioned externally to lower lip as reference, showing the exact position of FB in relation with the pen tip in the treatment area (Figures 3 and 4).

Therewith, the treatment with use of the fluoroscopy was successful, being possible to determine the direction of the local approach, and consequently removal of FB precisely and quickly. (Figure 5).

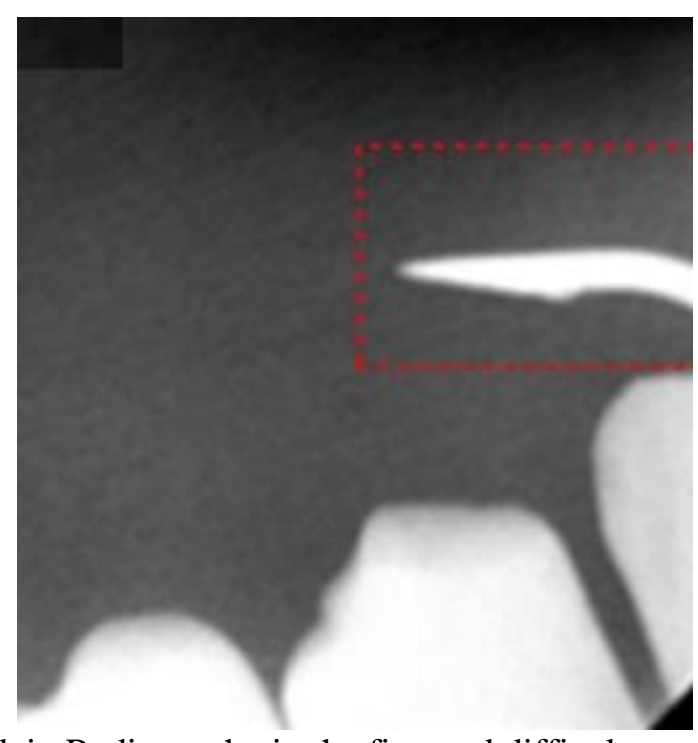

Figure 1: Plain Radiography in the first and difficult attempt to locate the foreign body (red squares).

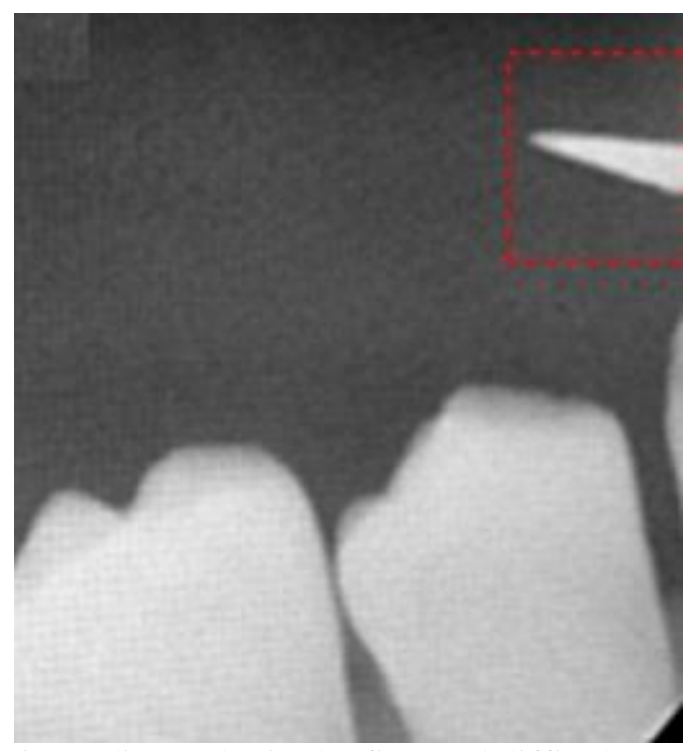

Figure 2: Plain Radiography in the first and difficult attempt to locate the foreign body (red squares).

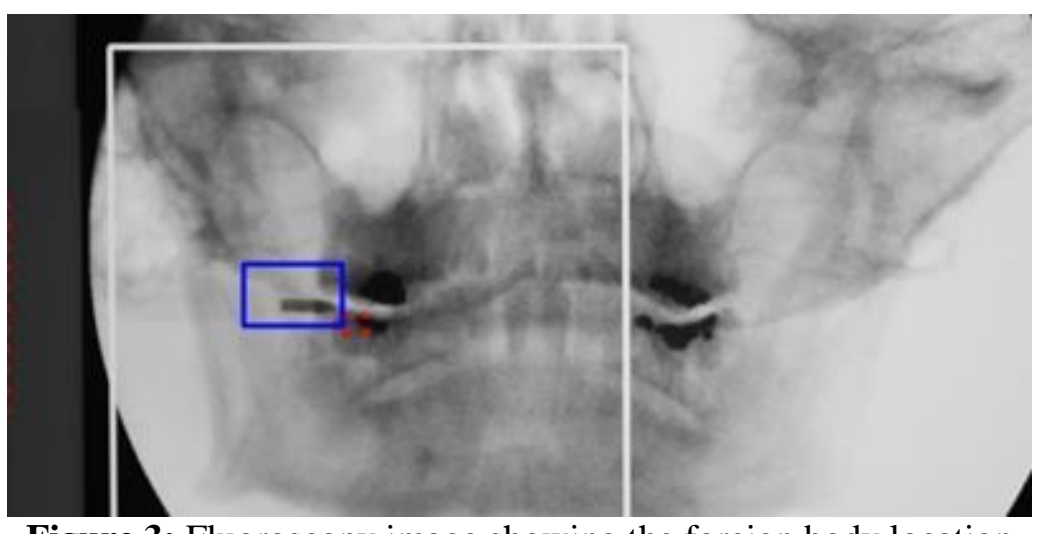

Figure 3: Fluoroscopy image showing the foreign body location (red square) with reference of a tip pen attached externally (blue square) and the anatomical spatial relationship.

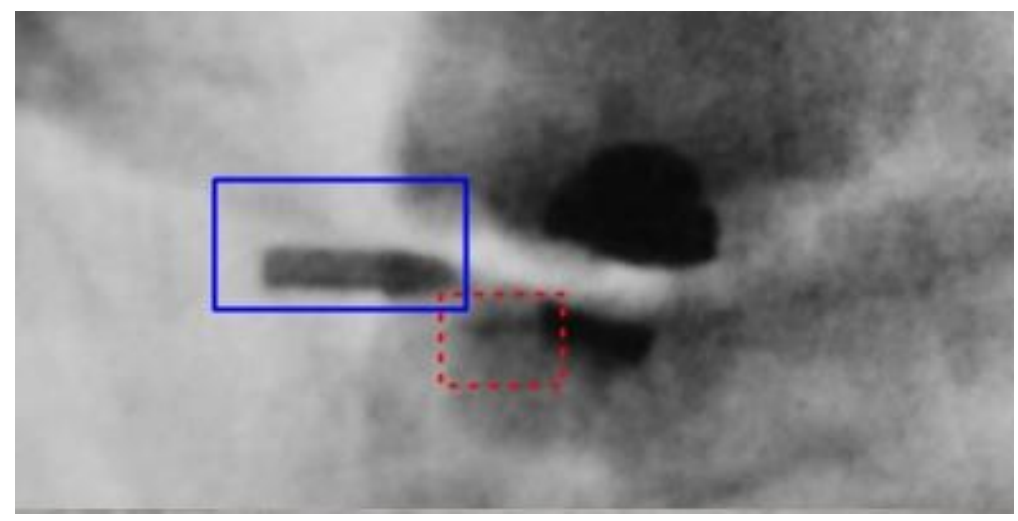

Figure 4: Fluoroscopy image with magnification that demonstrated exactly the location of foreign body (red square) in relation with the tip pen (blue square).

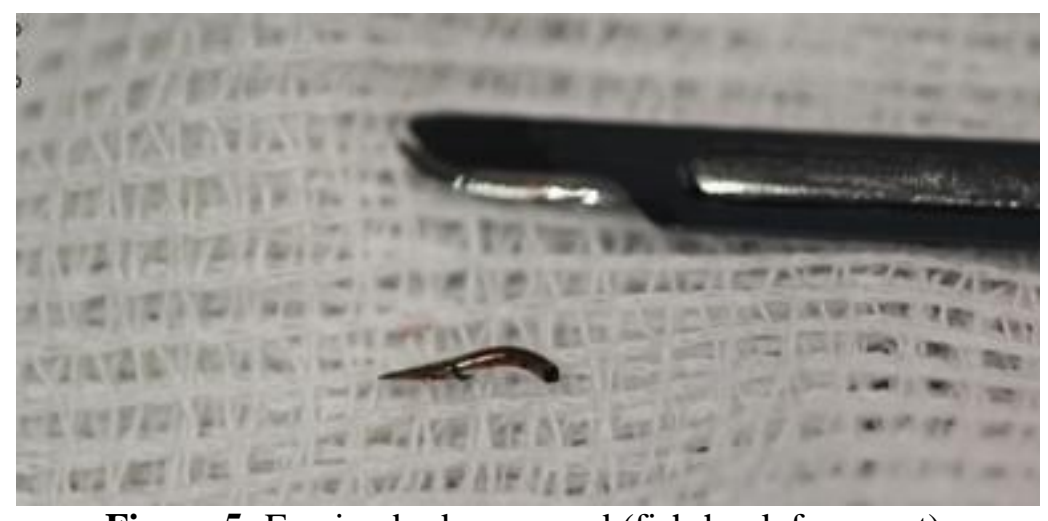

Figure 5: Foreign body removed (fish-hook fragment).

\section{DISCUSSION}

An adequate method is necessary to determine the exact location of a FB in the maxillofacial region, although the methods of removing are yet controversial. Our experience demonstrated that the removal of foreign bodies located in soft tissue could be more efficient with the aid of fluoroscopy method, mainly after a prior unsuccessful attempt of location with conventional radiography. Fluoroscopy get effectual results to the surgeon and subsequently beneficial to patient to treat FB in the maxillofacial region.

In support with this experience, recent reports show that the fluoroscopy has a high success rate to determine the precise location of FB when compared with the convention radiography method ${ }^{8,10,11}$. In our case was also possible to notate that the image intensifier provided a precise localization in relation with anatomy spatial relationships (Figure 3) that made more feasibly the removal than the plain radiography at first. In addition, as example our case, fluoroscopy leads a minimally invasive procedure, minimizing scars and injure to patient, considering the aesthetics aspects of face ${ }^{5}$.

Studies demonstrated that image intensifier is a useful and safe method to detect FB preoperative and intraoperative $e^{9,12}$. A advantage, this technique allows to obtain images of the foreign body's location in relation to the surgeon's tool reference ${ }^{13}$, such as the tip pen placed extraoral in our case. Thus, it permit a dimensional location of approach and incision placement along the object, preserving anatomic structures, as well decrease the possibility of crossoperative complications; reduce surgical time and tissue manipulation, as also described ${ }^{5,14}$.

The fluoroscopy besides permit guide with surgeon's tool reference also can provide real-time images that are fundamental to locate FB in soft tissue ${ }^{11,12}$. This advantages need to be considered, due to the tendency for a FB to move deeper soft tissues 5 . In addition, as example of our case, should consider the fish-hook's shape barbed inside the soft tissue, once that the retrograde movement can damage important structures. Based in this case, fluoroscopy showed to be an effective alternative for the removal of FB retained in the soft tissues, since it is precise, fast, with minimum risk of complications.

\section{CONCLUSION}

The authors suggest that in presence of foreign bodies in the maxillofacial region, the use of fluoroscopy as first choice is a reliable method for removal, avoiding discomfort to patient.

\section{REFERENCES}

1. Rudagi BM, Halli R, Kini Y, Kharkhar V, Saluja H. Foreign bodies in facial trauma-report of 3 cases. J Maxillofac Oral Surg. 2013; 12(2):210-3.

2. Bhatt C, Reddy NV, Reddy TN. Removal of sub-mucosal foreign body (metal wire) from the pharynx using image intensifier, J Laryngol Otol. 2003; 117(11):902-4.

3. Nezafati S, Shahi S. Removal of broken dental needle using mobile digital C-arm. J Oral Sci. 2008; 50(3):351-3 
4. Pandyan D, Nandakumar N, Qayyumi BN, Kumar S. Carm fluoroscopy: a reliable modality for retrieval of foreign bodies in the maxillofacial region. J Contemp Dent Pract. 2013; 14(6):1193-6.

5. Gui H, Yang H, Shen SG, Xu B, Zhang S, Bautista JS. Image-guided surgical navigation for removal of foreign bodies in the deep maxillofacial region. J Oral Maxillofac Surg. 2013; 71(9):1563-71.

6. de Mey J, Op de Beeck B, Meysman M, Noppen M, De Maeseneer M, Vanhoey $M$ et al., Real time CTfluoroscopy: diagnostic and therapeutic applications, Eur J Radiol. 2000; 34(1):32-40.

7. Takahashi M, Bussaka H, Nonaka N, Miura G, Hirata Y, Matsukado Y. Digital fluoroscopic angiography in the diagnosis of central nervous system diseases. Neurol Med Chir. 1983; 23(2):116-22.

8. Zhao JB, Chen Y, Zeng QL, He XF, Lu W, Mei QL, Li, YH. Removal of metallic foreign body in the soft tissue under fluoroscopy: 10 years of experiences. Nan Fang Yi Ke Da Xue Xue Bao. 2009; 29(12):2504-5, 2509.

9. Sencimen M, Bayar GR, Gulses A. Removal of the retained suture needle under $\mathrm{C}$-arm fluoroscopy: a technical note. Dent Traumatol. 2010; 26(6):527-9.

10. Sri-Pathmanathan R. The mobile X-ray image intensifier unit in maxillofacial surgery. Br J Oral Maxillofac Surg. 1990; 28(3):203-6.

11. Gans BJ, Kallal RH, Helgerson AC, Verona SR. The image intensifier in oral and maxillofacial surgery. J Oral Maxillofac Surg. 1982; 40(11):726-9.

12. Park SS, Yang HJ, Lee UL, Kwon MS, Kim MJ, Lee JH et al. The clinical application of the dental mini C-arm for the removal of broken instruments in soft and hard tissue in the oral and maxillofacial area. J Craniomaxillofac Surg. 2012; 40(7):572-8.

13. Yoganathan P, Conti SM, Kavalec C. The use of intraoperative fluoroscopy as an aid for removal of radiopaque intraorbital foreign bodies. Ophthalmic Surg Lasers Imaging. 2008; 39(5):436-7.

14. Su Y, Nan G. Using methylene blue as a marker to find and remove tiny metallic foreign bodies embedded in the soft tissues of children: a randomised controlled trial. Int J Surg. 2016; 29:43-8.

\section{CONFLICTS OF INTERESTS}

The authors declare no conflicts of interests.

\section{CORRESPONDING AUTHOR}

Gabriel Mulinari dos Santos

gabriel_mulinari@hotmailcom

Received 19/03/2018 Accepted 10/05/2018 